\title{
Network model for visually mediated ciliary locomotion in Hermissenda
}

\author{
Douglas A Baxter, ${ }^{*}$ Terry Crow \\ From Nineteenth Annual Computational Neuroscience Meeting: CNS*2010 \\ San Antonio, TX, USA. 24-30 July 2010
}

The overall goal of this study is to investigate the ways in which learning modifies behavior. A combination of computational and empirical studies is being used to address this issue. Empirical studies investigate learning from a cellular and synaptic perspective in the relatively simple nervous system of the nudibranch mollusk Hermissenda [1-3]. Pavlovian conditioning produces light-elicited inhibition of normal positive phototaxis in Hermissenda. Learning changes both cellular excitability and synaptic strength in the neural circuit that supports phototaxis. In the present study, a model of the circuit that supports visually mediated locomotion (Fig. 1A) was developed. Consistent with empirical observations, simulated responses to light increased the level of $\mathrm{VP}_{1}$ spike activity (Fig. 1B1), which is equivalent to positive phototaxis. Simulations indicated that phototaxis resulted from disinhibition of $\mathrm{VP}_{1}$. Light increased activity in $\mathrm{I}_{\mathrm{e}}$ and decreased activity in $\mathrm{I}_{\mathrm{i}}$ (Fig. 1B2). The net result was less activity in $\mathrm{III}_{\mathrm{i}}$ and disinhibition of $\mathrm{VP}_{1}$ (Fig. 1B2). Simulations also indicated that disinhibition produced phototaxis only if $\mathrm{VP}_{1}$ had a high level of tonic firing. The model is being refined and expanded, and will be used to investigate the generation of other behaviors (e.g., foot contraction), the responses to other
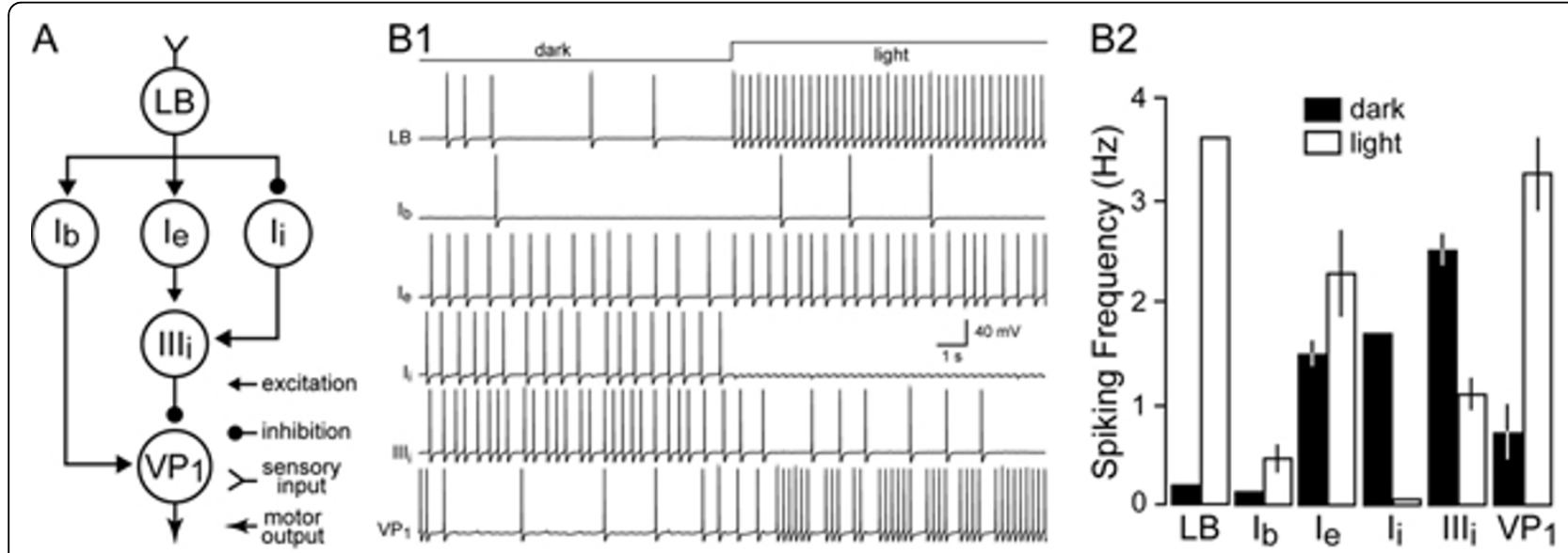

Figure 1 Network model for visually mediated ciliary locomotion. A: The model had six cells: LB, lateral B-type photoreceptor; $I_{b}, l_{e}, I_{j}$ and $I I I_{i}$, interneurons; VP 1 , ciliary motor neuron. The cells were Hodgkin-Huxley-like neurons. Membrane conductances also included noise. The match between empirical data and model properties was qualitative. For example, all synaptic connections were modeled as monosynaptic, which reflected 'functional' connections. The circuit was implemented in SNNAP [4]. B1: The model responded to light, which was simulated by depolarizing LB, with increased $V P_{1}$ activity. B2: The mean (+/- SD; $\left.n=7\right)$ spiking frequency $(\mathrm{Hz})$ of each cell before (dark) and during the light stimulus (light). Noise produced variability among simulations. In some cases, the error bars were not visible.

\footnotetext{
* Correspondence: Douglas.Baxter@uth.tmc.edu

Department of Neurobiology and Anatomy, The University of Texas Medical

School at Houston, Houston, TX 77030, USA
} 
sensory inputs (e.g., gravity), and the influence of learning-induced plasticity (e.g., increased $\mathrm{I}_{\mathrm{e}}$ excitability and decreased $\mathrm{VP}_{1}$ tonic firing). Simulations also will help identify features of the model that warrant further empirical investigation.

\section{Acknowledgements}

This work was supported by NIH grants P01 NS038310 and R01 MH058698.

Published: 20 July 2010

\section{References}

1. Crow T: Pavlovian conditioning of Hermissenda: Current cellular, molecular, and circuit perspectives. Learn Mem 2004, 11:229-238.

2. Crow T, Tian L-M: Pavlovian conditioning in Hermissenda: A circuit analysis. Biol Bull 2006, 210:289-297.

3. Crow T, Tian L-M: Neural correlates of Pavlovian conditioning in components of the neural network supporting ciliary locomotion in Hermissenda. Learn Mem 2003, 10:209-216.

4. Baxter DA, Byrne JH: Simulator for neural networks and action potentials. Methods Mol Biol 2007, 401(z):127-154, (SNNAP is available at http://www. snnap.uth.tmc.edu).

doi:10.1186/1471-2202-11-S1-P59

Cite this article as: Baxter and Crow: Network model for visually mediated ciliary locomotion in Hermissenda. BMC Neuroscience 2010 11(Suppl 1):P59.

\section{Submit your next manuscript to BioMed Central} and take full advantage of:

- Convenient online submission

- Thorough peer review

- No space constraints or color figure charges

- Immediate publication on acceptance

- Inclusion in PubMed, CAS, Scopus and Google Scholar

- Research which is freely available for redistribution

Submit your manuscript at www.biomedcentral.com/submit 